\title{
Chapter 7: Adaptive Governance: The Challenge for Regional Natural Resource Management
}

\author{
Jennifer Bellamy
}

\section{Introduction}

Concern for the sustainability of our interdependent social and natural systems is growing exponentially in policy and science arenas, both nationally and internationally, as exemplified by recent policy statements and debates on major environmental issues such as global climate change (e.g. Stern 2006; Cosier 2006; Environment Business Australia 2004), water use and management in Australia (e.g. The Wentworth Group 2003, 2006; NWC 2006) and the health of our natural ecosystems (e.g. Australian SOE Committee 2006; Morton et al 2003; Millennium Ecosystem Assessment 2005). Human induced changes are having significant impacts on our natural resources with major implications for issues such as social and economic development, sustainable livelihoods and environmental management. Peri-urbanisation, the growth of urban populations and the increase in rural non-farm economic activities are all part of a global transition that is rapidly reshaping not only our social systems but the pattern of land use and related pressures on our natural resources ${ }^{1}$. Diamond (2005) frames the problem in a recent book through a rhetorical question:

Australia illustrates in extreme form the exponentially accelerating horse race in which the world now finds itself ... On the one hand, the development of environmental problems in Australia, as in the whole world, is accelerating exponentially. On the other hand, the development of public environmental concern, and of private and public countermeasures, is also accelerating exponentially. Which horse will win the race? (p. 415-416)

This paper explores the complexity of natural resource governance within the framework of sustainable development and identifies challenges to an effective, legitimate and adaptive approach in practice. It considers prospects for more adaptive regional governance frameworks within the Australian federal system to address the accelerating and long-term challenges of the sustainability of our interconnected social and natural systems. 


\section{Sustainability: an evolving policy concept}

Sustainability $^{2}$ as an over-riding goal for society in general is arguably one of the greatest challenges currently facing human society. It is a complex, ambiguous and often contested concept which has generated much debate in the academic and political literature. As a concept, its focal emphasis has evolved over time. The contemporary interpretation of sustainability as an integrative concept encompassing the so-called 'triple bottom line' of environmental integrity, economic vitality and social cohesion evolved in Australian policy arenas in the 1990s (e.g. Commonwealth of Australia 1992; AFFA 1999; Bellamy and Johnson 2000; MDBMC 2001; Dovers and Wild River 2003). This interpretation places strong emphasis on:

- the interconnectedness of the triple bottom line dimensions;

- the long term nature of problem framing and of the related policy processes needed to address these three dimensions in tandem;

- equity, both within contemporary society (intragenerational) and in terms of the legacy of future generations (intergenerational); and

- the urgency of the need for action.

The 'triple bottom line' dimensions of sustainability are fundamental to progress towards Australia's preferred and sustainable future but they require considerable change in policy and institutional systems and structures.

Significantly, from local to global scales, linked social and natural systems do not respond to change in 'smooth' linear ways rather they are dynamic and characterised by accelerating complexity, uncertainty, disorganisation and irregular or sudden changes that are multilevel, difficult to predict and potentially irreversible or very difficult and costly to manage (e.g. Gunderson and Holling 2003; Berkes et al 2003). Moreover the multifunctional character of our interconnected social and natural systems involves multiple, but often conflicting, benefits (such as water supply, recreation, commerce, human health, ecosystem services), which are linked to a multiplicity of stakeholders (across governments, industry and community) with diverse and plural values, responsibilities and agendas, which may themselves be conflicting.

Contemporary interpretations emphasise sustainability as a process and a means to an end, rather than an end in or of itself. For example, Holling (2001) argues that:

Sustainability is the capacity to create, test, and maintain adaptive capacity. Development is the process of creating, testing and maintaining opportunity. The phrase that combines the two, 'sustainable development', thus refers to the goal of fostering capabilities and creating opportunities (p. 390). 
It is argued that for societies to deal with and shape change, they require 'adaptive capacity' based on shared understanding and management power through collaboration and partnerships that foster adaptation and learning (e.g. Berkes et al 2003; Folke et al 2005). Importantly such adaptive capacity resides in actors, social networks and institutions as well as ecosystems. This concept of adaptive capacity emphasises the ability of underpinning systems to adapt to or compensate for on-going transformative processes rather than just the ability of management approaches to maintain existing systems. As such, sustainability is as much about the flexibility and adaptive capacity of our underlying social and natural systems as it is about the ability of actors to manage change. Governance considerations are therefore central to an adaptive process.

Coupled with a perceived failure of top down governmental command-and-control approaches to resolving many natural resource issues, this shift in interpretation has led to increasing calls for new and more 'adaptive governance' of interconnected social and natural systems (e.g. Folke et al 2005; Scholz and Stiftel 2005; Howlett and Raynor 2006). A new generation of governance institutions is being experimented with by governments worldwide to address diverse issues relating to the uncertainties and dynamism of changing social and natural systems (e.g. Bellamy and Johnson 2000; Bellamy et al 2002; Innes and Boher 2003; Lebel et al 2006). These issues include: policy coordination and coherence; multidimensional and inequitable policy impacts (i.e. equity and social justice); power sharing; legitimacy (i.e. procedural justice and social acceptability); incomplete knowledge, technical uncertainty and ignorance; conflicting values and priorities; and urgency of response.

\section{Addressing sustainability: through a natural resource management lens}

In Australia, the current system and pattern of use and management of our natural resources has developed over a long period during times when people commonly considered these resources as largely unlimited in terms of capacity for productive use and when beliefs in people's rights to use their land as they wished were particularly dominant (e.g. Cocks 1992). For example Bates (2003) argues:

The governmental approach to natural resource management has had to be applied in the context of a social system that hitherto placed few restrictions on the exploitation of natural resources by private owners. The common law effectively allowed landowners to do what they wished with their land and its resources, subject only to the right of other landowners not to be unreasonably interfered with by such use ... It remains true that the most significant environmental problems facing Australia today have also proved to be the hardest for governments to tackle because they force regulators to confront the traditional rights of 
private landowners ... Attempts to curb degradation and destruction of natural resources on private land however; for example, clearance of native vegetation and forests, land degradation and loss of biodiversity in general, have historically proved difficult to introduce, and have been inadequate in their coverage, implementation and enforcement. Water and fisheries reform have also had to grapple with the difficulties inherent in modifying or removing entitlements that over the years have come to be regarded as de facto property rights (p.279-280).

Institutional arrangements for managing our natural resources traditionally involve numerous individual, single-function federal and state agencies, each pursuing its own legal mandate through developing and implementing policy dominantly focused on single issues (such as sustainable production, water supply or nature conservation). Over some period of time, this system developed numerous natural resource policies and government incentives (e.g. encouraging land clearing for development) which often proved to have conflicting or unintended and environmentally-undesirable effects (e.g. ANAO 1997; The Senate Committee Inquiry 2004).

With growing recognition that the impacts of past resource use policy and practices are becoming socially, economically and environmentally unacceptable, the term 'natural resource management' (NRM) emerged in the mid to late 1990s in Australian national and state policy arenas as an integrative and systemic concept to address the complex sustainability issues of our interconnected social and natural systems. In 1999, a federal policy discussion paper on Managing Natural Resources in Rural Australia for a Sustainable Future on developing a national policy for natural resource management defined NRM as 'protecting, maintaining and enhancing natural resources in rural Australia to provide the basis for sustainable production, healthy ecosystems (including healthy rivers and estuaries) and viable rural communities' (AFFA 1999, p.1). It also clearly argues that 'policy approaches for NRM need to be applied in an integrated way across regions and catchments and at the local or farm levels' (AFFA 1999, p.1).

\section{Governance for natural resource management}

\section{NRM as a wicked problem}

NRM addresses issues where it is often unclear where responsibilities lie and where traditionally no one sphere of government, agency, institution, or group of individuals has sole jurisdictional responsibility, such that problem solving capacity is widely dispersed and few actors or decision-makers can accomplish their mission alone (Innes and Booher 2003; Bellamy et al 2002, 2005). In a pluralistic society, therefore, NRM policy problems are what Rittel and Webber (1973) refer to as 'wicked'; namely, problems that 'defy efforts to delineate their boundaries and to identify their causes, and thus expose their problematic nature' 
(p. 167). Wicked problems are characterised by a number of inherent properties (Rittel and Webber 1973; Bellamy and Johnson 2000; Williams 2006). Firstly, they cannot be definitively described. Second, they do not respect fixed and conventional territorial or sectoral boundaries or spheres of government (i.e. bridge political, geographical and ideological boundaries). Third, they are persistent, complex, non-linear and irreversible and involve long time scales. Fourth, they are socially constructed and often disputed. Fifth, there are no optimal solutions or solutions with definitive and objective answers. Finally, they levy enormous costs and have broad consequences (social, economic, environmental).

Wicked NRM policy problems involve large and multifunctional spatial areas (i.e. rather than the use of a single resource by a local community), substantial institutional and organisational fragmentation, and require enduring and resourced collective responses across interdependent public, private and community sectors (e.g. Bellamy and Johnson 2000; Bellamy et al 2002; Connor and Dovers 2004). 'Collective action problems may occur because of a fragmented institutional setting that necessitates cooperation between a considerable number of actors with highly varying norms, interests and powers to act' (Saglie 2006, p. 9). Wicked problems therefore require coordination and cooperation across the horizontal and vertical dimensions of policy and institutional systems and structures including (e.g. Murray 2005, p. 28-29):

- horizontally across administrative boundaries;

- horizontally between agencies and departments within the same level of government when management components of a single natural system is fragmented between them;

- horizontally between government and non-government stakeholders who affect, or are affected by, natural resource management; and

- vertically when responsibility for management of the processes of an ecological or spatial natural unit rests with different levels of government and/or private actors.

Within the Australian federal system, wicked natural resource problems have profound implications for political problem framing and the design of credible and legitimate pathways towards sustainable futures. From local to global scales, the increasing and on-going challenges of wicked natural resource problems are imposing and their continuing emergence as fundamental political problems signifies the need for a new approach to their governance. Specifically, this paper argues these new approaches need to support the development of governance frameworks that encourage and support adaptation as our social and natural systems inevitably continue to evolve and change. 


\section{New NRM Governance: a response to a failed system?}

The traditional hierarchical governmental institutions for NRM are increasingly identified as unable to cope with contemporary 'wicked' natural resource problems (e.g. Bellamy and Johnson 2000; Connor and Dovers 2004; Scholz and Stiftel 2005; Sabatier et al 2005). In the context of sustainability, there is also a growing recognition that government alone does not determine the future direction of sectors in society; these are shaped through the interaction of many actors. In response, there has been a global trend in government of devolving specific decision-making closer to its source or context and an emphasis on developing partnerships, strategic alliances, networks and broader consultation with those who are likely to be responsible for, or experience impacts from, decisions (Bellamy et al 2003; Brown this volume; Head this volume). As Eckersely (2003) argues:

From a political perspective, ecological problems represent a major disjuncture in democratic accountability and control. This arises because there is no necessary connection between those who create ecological problems, those who have the expertise to understand them, those who suffer the negative consequences and those who must take political responsibility for them. If there is a general lesson from the eco-political literature, it is that many of these 'democratic deficits' in relation to political accountability and control may be remedied by new forms and styles of political communication which brings together as many disparate players as practicable (including culprits and beneficiaries, experts and laypeople, indigenous and 'settler' communities) into an open and constructive dialogue aimed at reaching broad social consensus (p. 492-3).

Stoker (1998) describes this global shift as 'the development of governing styles in which boundaries between and within public and private sectors have become blurred' (p. 17). The term 'governance' is a contested concept but it is increasingly used to signify this transition in patterns and processes of governing across a wide variety of policy areas (e.g. Stoker 1998; Bingham et al 2005; Swyngedouw 2005). Governance encompasses formal institutions of government and informal arrangements among government and non-government actors from the private sector and civil society (see Brown, this volume). In particular, governance is increasingly used within the NRM arena to refer to processes by which power is exercised and conflicts and interests are accommodated within an institutional context which emphasises participation, inclusiveness, deliberation and social and political learning. Three broad 'modes' of NRM governance commonly occur through (Bell and Park 2006):

- hierarchies (e.g. traditional forms of top-down control and regulation through the state);

- market-based forms of resource allocation; and 
- networks (involving various forms of public-private collaboration).

Significantly, with the emergence of network governance and increasing community expectations for more participatory and inclusive governance arrangements, it is argued that the 'new institutional 'fixes' have begun to challenge traditional state-centred forms of policy-making and have generated new forms of governance-beyond-the-state' (Swyngedouw 2005, p. 1991). The term 'new governance' has emerged as a descriptor for this mode of governing (e.g. Howlett and Raynor 2006; Bingham et al 2005). The notion of complexity is key to understanding the perceived failures of traditional hierarchical modes and the emergence of these new more participatory and deliberative governance approaches.

\section{Complexity and capacity}

NRM governance is typically highly complex and characterised by (e.g. Bressers and Kuks 2003): multiple levels of policy implementation; multi-actor character of policy implementation; multiple perceptions of the problem and the objectives of policy implementation; multiple strategies and policy instruments for policy implementation; and a complex multi-resourced and multi-organisational basis for implementation of policy.

The complexity of these characteristics relates not only to the functioning and outcomes of linked natural and social systems but also to the capacity to subject them to adaptive administrative management. In the NRM arena, therefore, new governance approaches aim to address 'wicked' natural resource problems occurring within complex multilevel and multi-actor settings based on a more holistic approach to problem framing and policy implementation. They focus, in particular, on participation, deliberative processes, collaborative relationships, networks and consensus building processes that serve 'as mechanisms for cooperation and coordination among diverse and often rival participants in the policy process' (Bingham et al 2005, p.551). Folke et al (2005) point out that governance of linked social and natural systems 'generally involves polycentric institutional arrangements, which are nested quasi-autonomous decision-making units operating at multiple scales' (p. 449). These arrangements involve 'local, as well as higher, organisational levels and they aim at finding a balance between decentralised and centralised control' (Folke et al 2005). These complex governance systems have multiple centres or authorities and, although typically multilayered, they are not necessarily neatly hierarchical (Lebel et al 2006).

Expectations are high for the new more participatory and inclusive modes of NRM governance. For example, Bingham et al (2005) identify that:

Advocates argue that new governance processes promote increased collaboration among government, business, civil society, and citizens; enhance democratic decision making; and foster decisional legitimacy, 
consensus, citizen engagement, public dialogue, reasoned debate, higher decision quality, and fairness among an active and informed citizenry. They contend that these processes promote individual liberty while maintaining accountability for collective decisions; advance political equality while educating citizens; foster a better understanding of competing interests while contributing to citizen's moral development; and orient an atomised citizenry toward the collective good (p. 554).

Notwithstanding, there is considerable debate concerning their capacity to answer many of the pathologies of adversarial top-down policy systems and support a transition toward desired social, economic and environmental outcomes. For example, many question their capacity to:

- $\quad$ reduce conflicts and transaction costs (e.g. Lubell 2004; Saglie 2006);

- promote public participation and policy dialogue (e.g. Innes and Booher 2003; Leach et al 2002);

- foster deliberative processes (e.g. Connelly et al 2006; Lebel et al 2006);

- Lead to more cooperative behaviour (e.g. Lubell 2004; Scholz and Stiftel 2005; Kenney 2000; Sabatier et al 2005);

- devolve power (e.g. Lane et al 2004; Bell and Park 2006);

- be more democratic and equitable in relation to the legitimacy of process and outcome (e.g. Lane and Corbett 2005; Leach 2006; Moore and Rockloff 2006; Connelly et al 2006); or

- improve environmental and social conditions (e.g. Bellamy and Johnson 2000; Kenney 2000; Lubell 2004).

The next section of this paper examines some of these issues in the context of a shift to regional NRM governance in Australia.

\section{NRM Governance in Australia: a complex federal system}

\section{Multi-layered, fragmented and ad hoc}

The current management of Australia's natural resources is multi-jurisdictional involving cooperative arrangements of the three spheres of government national, state/territory and local (e.g. Bates 2003; WalterTurnbull 2006). Under the Australian Constitution, responsibility for the legislative and administrative framework within which natural resources are managed lies with the State and Territory governments, who in turn have traditionally devolved some responsibilities particularly relating to land use and development planning to local governments. The Australian Government's involvement in NRM focuses dominantly on matters of national environmental significance and fulfilling Australia's international obligations. The laws that are made for NRM matters by the federal government draw their validity from other heads of power in the 
Constitution, such as taxation power, trade and commerce or external affairs power (HRSCEH 2000). But as Bates (2003) points out:

It has been clearly established through a number of decisions of the High Court of Australia, over the past 25 years, that the Commonwealth Government has undoubted constitutional powers to override state decision-making on the use and management of natural resources. In practice, however, since the heyday of federal intervention in the 1980s, political constraints have influenced any decision to use these powers. The Commonwealth and States have now adopted a more cooperative approach to environmental protection and natural resource management ... This 'co-operative' federalism has been reflected in recent years through the Commonwealth Government basically adopting an initiation and co-ordination role with respect to the development of national policies for resource management and environmental protection ( $p$. 284-5).

The shared responsibility between the Commonwealth and the States referred to as 'cooperative federalism' is reflected, for example, in the Intergovernmental Agreement on the Environment which was signed by the Commonwealth and all States and Territories in 1992. The purpose of this agreement was to achieve sound environmental management through a system of parallel and complementary legislation. Under this agreement, consultation between the Australian, State and Territory governments in practice is formalised through ministerial councils, standing committees and a range of consultative committees that also include key industry, scientific and local government representatives. Since the late 1980s, however, a fourth regional tier of responsibility for NRM has been introduced by state and territory governments through a broad range of different statutory and non-statutory arrangements within each jurisdiction (e.g. Bellamy et al 2002, 2003; Dovers and Wild River 2003). Although particular responsibilities can vary according to the legislative environment and the administrative arrangements within a particular jurisdiction, the traditional division of responsibilities between the levels of government, regional authorities and individual land owners in Australia for natural resource management are summarised in Table 7.1. 
Table 7.1. Typical division of responsibilities for natural resource management in Australia

\begin{tabular}{|l|l|l|l|l|l|}
\hline Jurisdiction Activity & Commonwealth & State & $\begin{array}{l}\text { Region (i.e. } \\
\text { Catchment } \\
\text { Management } \\
\text { Authority) }\end{array}$ & $\begin{array}{l}\text { Local } \\
\text { govern-ment }\end{array}$ & $\begin{array}{l}\text { Individuals / } \\
\text { corpor-ations }\end{array}$ \\
\hline $\begin{array}{l}\text { Adherence to international / national } \\
\text { conventions }\end{array}$ & $* * *$ & $* *$ & $*$ & $*$ & $*$ \\
\hline Leadership and catalysing change & $* * *$ & $* * *$ & $* * *$ & $* * *$ & $*$ \\
\hline $\begin{array}{l}\text { Administer land and water legislation } \\
\text { and regulation }\end{array}$ & $*$ & $* * *$ & - & $* *$ & - \\
\hline Undertake regional and local planning & $*$ & $* *$ & $* * *$ & $* * *$ & $*$ \\
\hline Support for research and development & $* * *$ & $* * *$ & $*$ & $*$ & - \\
\hline Development of national NRM policy & $* * *$ & $* *$ & $*$ & $*$ & $*$ \\
\hline $\begin{array}{l}\text { NRM extension and community capacity } \\
\text { building }\end{array}$ & $*$ & $* * *$ & $* *$ & $* *$ & $*$ \\
\hline $\begin{array}{l}\text { On-ground management (except for } \\
\text { crown lands) }\end{array}$ & - & - & $* *$ & $* *$ & $* * *$ \\
\hline On-ground management of crown lands & $* * *$ & $* * *$ & $* *$ & $*$ & - \\
\hline
\end{tabular}

Levels of responsibility

- Not relevant

* Low

${ }^{* *}$ Medium

*** High

Source: HRSCEH 2000, p. 27

Although in practice all three spheres of government in Australia (local, state and federal) have demonstrated a significant involvement in NRM policy initiatives, such initiatives have generally developed independently of each other in an ad hoc way (Bellamy et al 2002; Connor and Dovers 2004). This has led to a diversity of NRM institutional arrangements existing across Australia and within any state/territory or region (see Bellamy et al 2002; The Senate Committee 2004; Keogh et al 2006; WalterTurnbull 2006). Not only does each level of government typically adopt its own NRM governance approach but state and federal governments often continue to develop policy as well as design and implement program-specific arrangements that differ in scale, style, resourcing and accountability standards within themselves. These fragmented institutional arrangements may well involve competing objectives and interests.

NRM governance within Australia's federal system, therefore, involves a complex system of multiple 'nested' or polycentric decision-making arrangements (versus neatly hierarchical) being carried out concurrently across a range of political decision-making levels (e.g. national, state, region, local) and horizontally across a fragmented array of territorial and sectoral areas. It is presented diagrammatically in Figure 7.2. This system is continually evolving at all political and sectoral levels. For example, each state or region is evolving in different ways, for different reasons, in varying contexts and at different rates. At each 
level of this complex multi-layered and polycentric system, there are different emergent properties and problems to be addressed. Moreover, the different levels may be coupled by a diverse range of relationships that involve an iterative process of devolution and feedback of functions and outcomes within and between different decision-making levels (e.g. federal to local and vice versa).

Figure 7.2. NRM governance - a complex multi-layered and polycentric system
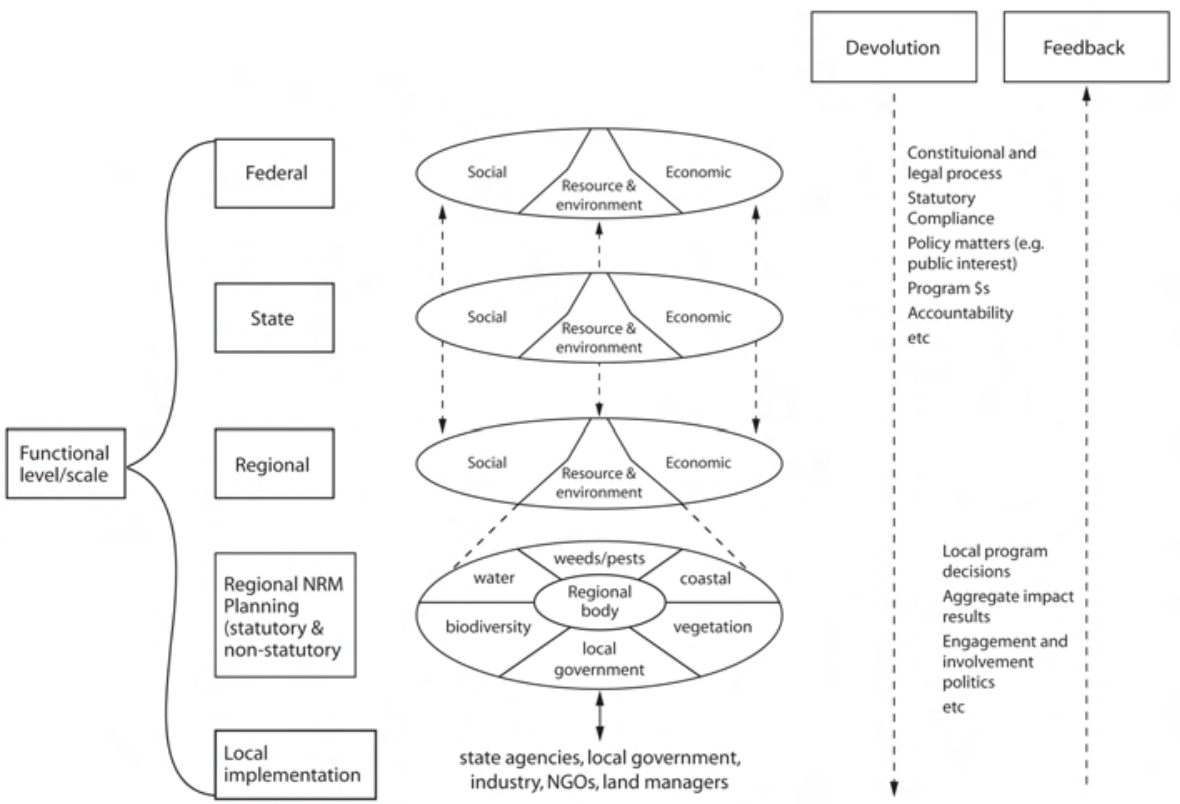

Source: Bellamy and McDonald (2005)

As a consequence of this ad hoc, polycentric and multi-layered development, constitutional constraints and fragmented institutional arrangements have obstructed an integrated and systemic national approach to managing Australia's natural resources. The result is a national agenda for NRM operating through a mix of parallel arrangements (i.e. cooperative federalism) that involve (Maher et al 2001, p.25):

- high level multi- and bi-lateral agreements between Commonwealth and State governments usually about specific aspects of NRM;

- leverage exerted by the Commonwealth Government through making State government access to Commonwealth financial resources based on meeting specified conditions;

- issue-based parliamentary inquiries; and

- an emerging Commonwealth presence in impact assessment in relation to matters of national environmental significance. 
This national agenda is increasingly emphasising a regional focus for NRM, which in practice is fundamentally dependent on a cooperative approach involving all three spheres of government, as well as relevant industry and other private actors.

\section{Shift to a regional focus: regional delivery for NRM}

Over the last two decades, Australian governments and regional communities have make considerable investments in NRM governance experiments at the regional scale grounded in the underlying assumptions of an emerging sustainability paradigm of change, adaptation and learning (e.g. AFFA 2002; Bellamy et al 2002, 2003; Head and Ryan 2004). These new regional governance approaches focus on wicked natural resource problems and emphasise broad participation and deliberation through the development of partnerships, strategic alliances and broader consultation between those with policy authority and those with significant stakes in decisions.

Significantly, a major shift in the framework of the federal NRM program delivery in Australia has occurred since 2000 with critical implications for adaptive NRM governance. This shift involved the introduction of a succession of Australian Government NRM policy initiatives emphasising joint regional delivery arrangements for the second phase of the National Heritage Trust (NHT) and the National Action Plan for Salinity and Water Quality (NAP). These new regional delivery arrangements are an example of cooperative federalism involving attempts by the Australian Government to devolve the management of natural resources to a more integrated and cohesive NRM approach through the creation of mechanisms for community-based NRM based on the establishment of accredited regional NRM bodies (see AFFA 2000, 2002; WalterTurnbull 2006).

Through the new regional delivery arrangements, 56 NRM regions are defined across Australia by spatial boundaries relating largely to natural biophysical characteristics (e.g. catchments and bioregions) and their intersection with state and territory boundaries. The primary purposes of the regional bodies are to guide NRM planning strategy and investment priorities within their respective regions, and to provide the mechanism for greater community-based NRM. The core elements of the institutional arrangements supporting regional NRM delivery include (e.g. WalterTurnbull 2006; Bellamy et al 2005):

- Bilateral agreements between the Australian Government and each of the State/Territory governments signed off progressively over a number of years (2001 to 2004). They include requirements for policy and institutional reforms consistent with national priorities and the relationship between the State/Territory governments for the delivery of regional funding. Each State/Territory has negotiated agreements with variations in accordance with State NRM policy requirements and NRM delivery arrangements; 
- Partnership agreements signed between respective state/territory governments and each regional body in their jurisdiction;

- Joint Steering Committees established separately for each state/territory and which are the main vehicle for bilateral decision-making and development of recommendations to Australian and State/Territory ministers in relation to regional delivery of NRM;

- Lead NRM State/Territory agency nominated to facilitate the delivery of the regional component of the NAP and NHT within each State and Territory jurisdiction; and

- Financial resourcing through parallel NAP and NHT programmatic 'block funding' mechanisms based on accredited regional investment strategies developed collaboratively by each regional body.

As Head and Ryan (2004) argue, this new form of regional governance 'changes the role of government to framework-setter, co-funder and facilitator, representing an adaptive form of public management. Governance is managed through a strategic framework of cooperation rather than primarily through regulatory and legal mandate' (p. 377). The role of federal and state governments however remains critical in establishing program direction, boundaries and resourcing.

Importantly, the regional delivery model is a new governance approach that operates within, and does not replace, an overarching framework of legislation, policy, and defined stakeholder responsibilities implemented by multiple, overlapping (and often competing) formal and informal NRM arrangements. Rather, the new regional NRM delivery approach operates concurrently with the existing polycentric system of nested arrangements, both 'horizontal' and 'vertical', between different actors (e.g. business/industry groups, community organisations, government agencies and politicians) and between different spheres and functional areas of government. The outcome is a unique regional NRM governance system for each State and Territory each operating through a different set of institutional arrangements. For example, there is considerably variation across the States and Territories in terms of the statutory status (and powers) of regional NRM bodies themselves, the membership and resourcing arrangements of these bodies and the role and powers of local government in relation to NRM and their linkages to regional NRM bodies and delivery processes. Importantly, overall these systems require cooperation of all three spheres of government, industry and other private actors and, in practice to-date, they largely involve more representative democratic structures rather than truly embracing participative democracy.

Not surprisingly, the implementation of the new regional NRM governance is proving a difficult challenge for the individuals, the institutions and the communities concerned and as a consequence, actual impact is often perceived 
to fall short of expectation (e.g. Bellamy and Johnson 2000; Lane et al 2004; Lane and McDonald 2005; Farrelly 2005; Moore 2005; Moore and Rockloff 2006). There are numerous and often conflicting social and institutional challenges imposed by the complex and fragmented polycentric character of Australia's federal system for NRM. Many of these challenges reflect on the capacity for more adaptive regional governance for NRM within the Australian federal system. Key challenges include:

- balancing traditional business and industry development interests with social and environmental constraints.

- competing or contradictory statutory and policy objectives and strategies arising from the breadth of sectoral concerns involved in regional NRM systems and the complex interrelationships between them;

- contest over the optimum degree of openness and inclusiveness in the setting of regional objectives and priorities to foster community ownership and commitment;

- complex transboundary problems (territorial and sectoral) and the related challenge of creating linking and bridging devices (that is structures, processes, mechanisms and people) to enable an integrated and collective perspective;

- developing whole-of-government responses to regional demands;

- turf issues, including the need to balance cooperation and competition because organisational self-interest is still heavily engrained in regional systems;

- conflicting values, including competing influences of industry groups and non-governmental groups or organisations on legislation and policy outcomes;

- conflicting approaches to the recognition of cultural diversity and difference;

- resource constraints including the adequacy of regional shares of public revenues, resources and regulatory powers; and

- knowledge sharing including the application of a more holistic and integrated science that crosses traditional knowledge boundaries and gives greater status to 'grass roots' or societal knowledge.

These challenges provoke a vital question about where the implementation of regional NRM within the Australian federal system is heading in terms of institutional arrangements, adaptive capacities and technical performance.

\section{The way forward: a question of adaptive capacity?}

Notwithstanding the fact that, as a wicked policy problem, NRM poses significant governance challenges, it is increasingly evident that a regional and systemic focus in NRM is a critical mechanism for addressing the sustainability of our interconnected natural and social systems. So what are the essential elements of 'good' adaptive regional NRM governance? Essential attributes recognised both 
nationally and internationally include (e.g. Folke et al 2005; Bellamy et al 2006; Lebel et al 2006; Davidson et al 2006):

- Participatory: engagement with stakeholders being inclusive of the range of values of people involved or affected by NRM decision-making. Critical for building trust and legitimacy;

- Deliberative: accommodating debate, dissent, mediation and negotiation. Critical for developing shared understanding and trust and enhancing adaptive capacity;

- Multi-layered: not necessarily neatly hierarchical but able to handle scale-dependent governance challenges and territorial or sectoral cross-boundary interactions and coordination. Critical to adaptive responses at appropriate levels;

- Nested: multiple centres or authorities for creating opportunities for understanding and for servicing needs in spatially heterogeneous contexts. Critical for providing flexibility for adapting to local contexts (i.e. knowledge, values, community capacity for action and social and environmental conditions) and creating appropriate learning and decision-making opportunities;

- Accountable and responsive: relating to both local communities and higher authorities in terms of decisions and actions that are responsive to changing circumstances, performance, knowledge and societal objectives and preferences. Critical to efficiency and adaptive capacity of regional NRM governance to respond to and shape change in the long term;

- Just: that is, social justice in relation to the distribution of benefits and involuntary risks. Critical to enhancing the adaptive capacity of vulnerable groups and society as a whole; and

- Well informed: embracing new forms of knowledge to deal with complexity and uncertainty associated with change in interconnected social and natural systems. Critical to social acceptability and adaptive governance capacity.

Is it possible to design and implement such an adaptive regional NRM style of governance within the Australian federal system that is effective, legitimate and durable in delivering sustainable outcomes for our linked social and natural systems? Although the 'jury is still out' on the outcomes of the new regional NRM delivery experiments, the multi-layered and polycentric nature of Australia's federal system for NRM is revealing some opportunities for a more adaptive, participative and deliberative regional style of governance.

A number of key lessons are emerging from current regional NRM practice that are critical elements necessary for enhancing adaptive capacity of NRM governance within Australia's federal system. Firstly, the regional focus is broadening the scope and scale of the collaboration on NRM (that is, both geographically large and institutionally broad and multi-levelled). Second, it is 
fostering new forms of participation of regional communities in NRM policy decision-making through changing the roles of state and societal actors and allowing social actors more capacity to coordinate amongst themselves and make collective decisions on action in the pursuit of societal goals with less central government control. Third, it is enabling the emergence of new network configurations or arrangements that connect individuals, organisations, agencies and institutions at multiple organisational or political levels. These inevitably have potential to enhance cooperation amongst the different spheres of government, communities and individual decision-makers who all act or have influence at multiple political scales. Fourthly, a clear recognition is emerging of the central role of local government in regional NRM and its delivery; although to date there has been very limited devolution of powers and limited capacity present in local government to enable this increasing role to be realised (see Bell this volume, Berwick this volume). Finally, it is encouraging new mechanisms for linking science, policy and society in which 'science' is more 'nested' in decision making, rather than external to it. Such mechanisms have greater capacity to value and engage multiple sources of knowledge and also the potential to provide improved opportunities for collaborative learning.

Although regional NRM governance is not the sole solution or panacea for NRM within our complex federal system (see Head and Ryan 2004; Lane and McDonald 2005; Moore 2005; Bell and Park 2006), these emerging attributes have promising implications for the potential of more participative and deliberative regional governance approaches to enhance adaptive capacity in our interconnected social and natural systems.

Undoubtedly, as Brown (this volume) proposes, substantive reform in Australia's complex federal system of government is ultimately critical to the move towards social, economic and environmental sustainability. Given the urgency for response posed by the sustainability challenge, in the short to medium term, what is evident is the need for an enabling environment for the regional NRM agenda that moves beyond the current limited focus on an adaptive form of public management (i.e. administrative adaptiveness) towards a more adaptive NRM governance system that enables social and political learning at multiple levels and 'nested' centres of decision-making across public and private sectors. At the most basic level, such an NRM governance system would need to:

- encompass the existing and emerging regional NRM roles and functions (including powers, responsibilities and resources) of the current three spheres of government;

- enable a cooperative and deliberative (rather than hierarchical) governance style;

- accommodate diversity in NRM policy development and implementation strategies (e.g. a mix of networks, hierarchies, and market-based instruments); 
- be sufficiently flexible to allow adaptation to diverse and changing local regional contexts and circumstances; and

- $\quad$ value and enable the sharing of multiple knowledge systems.

Substantive structural reform of our Australian federal system to a two, alternative three or a four tiered federal system is inevitably a long term agenda. Any decision for such reform however must recognise the interconnectedness of social and natural systems and involve consideration of all sectoral policy arenas concurrently (i.e. health, education, economic development, infrastructure, environment, etc.) to more effectively and legitimately enhance the adaptive capacity of society and its related institutions to deal with and shape inevitable change.

\section{References}

Agriculture, Forests and Fisheries Australia (AFFA) 1999, Managing Natural Resources in Rural Australia for a Sustainable Future: A discussion paper for developing a national policy. December 1999, AFFA, Canberra.

2000, Our Vital resources: National Action Plan for Salinity and Water Quality in Australia, October 2000.

2002, Framework for the Extension of the Natural Heritage Trust.

Australian National Audit Office (ANAO) 1997, Commonwealth natural resource management and environment programs. Australia's land, water and vegetation resources, The Auditor General, AGPS, Canberra.

Australian State of Environment Committee 2006, Australian State of the Environment 2006. Independent Report to the Australian Government Minister for the Environment and Heritage, Department of Environment and Heritage, Canberra, viewed 7 December 2006, <http://www.deh.gov.au/ soe/2006/publications/report/index.html>

Bates, G. 2003. 'Legal perspectives' in S. Dovers and S. Wild River (eds), Managing Australia's Environment, The Federation Press, Sydney, pp. 255-301.

Bell, S. and A. Park, 2006, 'The problematic metagovernance of networks: Water reform in New South Wales', Journal of Public Policy, vol. 26 (1), pp. 63-83.

Bellamy, J. 2006. 'Appendix A. Development of a case study synthesis framework' in G. McDonald, S. Hovermann, S. Heyenga and B. Taylor (eds), Case Studies in Regional Natural Resource Management in Northern Australia. Milestone Report 5. Healthy Savanna Planning Systems Project. Tropical Savanna Management CRC. June 2006, pp. 110-117. <http://savanna.cdu.edu.au/research/projects/healthy_savanna_pla.html > 
Bellamy, J.A. and A.K.L. Johnson, 2000, 'Integrated Resource Management: Moving from rhetoric to practice in Australian agriculture', Environmental Management Vol. 25 (3), pp. 265-280.

Bellamy, J. and G. McDonald, 2005, 'Through multi-scaled lenses: A systems approach to evaluating natural resource management policy and planning', in J. Bellamy (ed.), Regional natural resource management planning: the challenges of evaluation as seen through different lenses, CIRM Monograph Series, June 2005, The State of Queensland, Department of Natural Resources and Mines, Indooroopilly, pp.3-10, viewed 20 January 2007, $<$ http://www.cirm.org.au/publications/Monograph.pdf $>$

Bellamy, J., H. Ross, S. Ewing and T. Meppem, 2002, Integrated Catchment Management: Learning from the Australian Experience for the MurrayDarling Basin. Final Report. January 2002. A Report for the Murray Darling Basin Commission, CSIRO Sustainable Ecosystems, Brisbane, viewed 20 January 2007, <http://www.mdbc.gov.au/naturalresources/icm/icm_aus_x_overview.html>

Bellamy, J., T. Meppem, R. Gorddard and S. Dawson, 2003, 'The changing face of regional governance for economic development: Implications for Local Government', Sustaining Regions vol. 2 (3) Winter 2003, pp. 7-17.

Bellamy, J., D. Metcalfe, N. Weston, and S. Dawson, 2005. Evaluation of invasive species (weeds) outcomes of regional investment. Final Report to the Department of Environment and Heritage and Department of Agriculture, Fisheries and Forestry. November 2005. CSIRO Sustainable Ecosystems and the Rainforest CRC. <http://www.nrm.gov.au/monitoring/national-evaluations/weeds.html $>$

Berkes, F., J. Colding and C. Folke (eds) 2003, Navigating Social-Ecological Systems. Building resistence for complexity and change, Cambridge University Press, UK.

Bingham, L. B., T. Nabatchi and R. O'Leary, 2005, 'The new governance: Practices and processes for stakeholder and citizen participation in the work of government', Public Administration Review, vol. 65 (5), pp.547-558.

Bressers, H.T. and S.M.M. Kuks, 2003, 'What does 'governance' mean? From conception to elaboration', in H. A. Bressers and W.A. Rosenbaum (eds), Achieving Sustainable Development, Praeger, Westport, Connecticut, pp. 65-88.

Cocklin, C. and J. Dibden (eds) 2005, Sustainability and change in rural Australia, UNSW Press, Sydney, Australia.

Cocks, D. 1992, Use with Care: Managing Australia's natural resources in the Twenty First Century, NSW University Press, Kensington, Australia. 
Commonwealth of Australia 1992, National Strategy for Ecologically Sustainable Development. December 1992, AGPS, Canberra.

Connelly, S., T. Richardson and T. Miles, 2006, 'Situated legitimacy: Deliberative arenas and the new rural governance', Journal of Rural Studies, vol. 22, pp.267-277.

Connor, R. and S. Dovers, 2004, Institutional Change for Sustainable Development, Edward Elgar Publishing, Cheltenham, UK.

Cosier, P. 2006, 'Will Climate Change Cost Us the Earth', paper presented at The Green Capital Conference, Sofitel Wentworth, Sydney, 8 November 2006, viewed 20 November 2006, <http://www.wentworthgroup.org/docs/Will_climate_change_cost_us_the_Earthl.pdf $>$

Davidson, J., M. Lockwood, A. Curtis, E. Stratford and R. Griffith, 2006, Governance principles for Natural Resource Management, Report No. 1 of the Project Pathways to good practice in regional NRM governance, viewed 20 January 2007, <www.geog.utas.edu.au/geography/nrmgovernance/>

Diamond, J.M. 2005, Collapse: how societies choose to fail or survive, Penguin Group, Camberwell, Victoria.

Dovers, S. and S. Wild River (eds) 2003, Managing Australia's Environment, The Federation Press, Sydney.

Eckersley, R. 2003, 'Politics and Policy', in S. Dovers and S. Wild River (eds), Managing Australia's Environment, The Federation Press, Sydney, pp. 485-500.

Environment Business Australia 2004, New Tools and Old Myths: Climate change action - a toolkit for transition, A discussion paper issued by Environment Business Australia at CoP10, Buenos Aires, December 2004, viewed 18 November 2006, <http://www.environmentbusiness.com.au/conference_papers/the \%20toolbox.pdf $>$

Eversole, R. and J. Martin (eds) 2005, Participation and Governance in Regional Development: Global Trends in and Australian Context, Ashgate, Hampshire, England.

Farrelly, M. 2005, ‘Regionalisation of environmental management: A case study of the Natural Hertitage Trust, South Australia', Geographical Research, vol. 43(4), pp.393-405.

Folke, C., T. Hahn, P.Olsson and J. Norberg, 2005, 'Adaptive governance of social-ecological systems', Annual Review of Environmental Resources, vol. 30, pp.441-473.

Gunderson, L.H. and C.S. Holling (eds) 2003, Panarchy: Understanding Transformations in Human and Natural Systems, Island Press, Washington. 
Head, B. and N. Ryan, 2004, 'Can co-governance work? Regional natural resource management in Queensland, Australia', Society and Economy, Vol. 26 (2/3), pp.371-393.

Holling, C.S. 2001, 'Understanding the complexity of economic, ecological, and social systems', Ecology, vol. 4, pp. 390-405.

House of Representatives Standing Committee on Environment and Heritage (HRSCEH) 2000, Co-ordinating Catchment Management. Report of the Inquiry into Catchment Management, The Parliament of the Commonwealth of Australia, Canberra, December 2000.

Howlett, M. and J. Rayner, 2006, 'Convergence and divergence in 'New Governance' arrangements: Evidence from European Integrated Natural Resource Strategies', Journal of Public Policy, vol. 26 (2), pp. 167-189.

Innes, J.E. and D.E. Booher, 2003, The impact of collaborative planning on governance capacity. Working Paper 2003-03, Institute of Urban and Regional Development, University of California, Berkeley.

Keogh, K., D. Chant and B. Frazer, 2006, Review of Arrangement for Regional Delivery of Natural Resource Management Programmes, Report prepared by the Ministerial Reference Group for Future NRM Programme Delivery, Final Report, March 2006, viewed 20 December 2006, <http://www.nrm.gov.au/publications/regional-delivery-review/index.html>

Kenney, D.S. 2000, Arguing about consensus; Examining the case against Western watershed initiatives and other collaborative groups active in natural resource management, Natural Resource Law Centre, University of Colorado School of Law, Boulder.

Lane, M.B. and T. Corbett, 2005, 'The tyranny of localism: Indigenous participation in community-based environmental management', Journal of Environmental Policy and Planning, vol. 7(2), pp.141-159.

Lane, M.B. and G. McDonald, 2005, 'Community-based environmental planning: Operational dilemmas, planning principles and possible remedies', Journal of Environmental Planning and Management, vol.45 (5), pp. 709731.

Lane, M.B., G.T. McDonald, and T.H. Morrison, 2004, 'Decentralisation and environmental management in Australia: A comment on the prescription of the Wentworth Group', Australian Geographical Studies, vol. 42, pp.398-403.

Leach, W.D., N.W. Pelkey, and P.A. Sabatier, 2002, 'Stakeholder partnerships and collaborative policy-making: Evaluation criteria applied to watershed 
management in California and Washington', Journal of Policy Analysis and Management, vol. 21 (4), pp. 645-670.

Leach, W.D. 2006, 'Collaborative public management and democracy: Evidence from Western watershed partnerships', Public Administrative Review, vol. 66, Special Issue December, pp. 100-110.

Lebel, L., J.M., Anderies, B. Campbell, C. Folke, S. Hatfield-Dodds, T.P. Hughes and J. Wilson, 2006, 'Governance and the capacity to manage resilience in regional social-ecological systems', Ecology and Society, Vol. 11(1), 19 [on-line] URL: <http://www.ecologyandsociety.org/voll1/issl/art19/>.

Lubell, M. 2004, 'Collaborative environmental institutions: All talk and no action?', Journal of Policy Analysis and Management, vol. 23(3), pp. 549573.

Maher, M., J. Nevill, and P. Nichols, 2002, Improving the legislative basis for river management in Australia - Stage 2 Report, Land and Water Australia, Canberra.

Millennium Ecosystem Assessment 2005, Ecosystems and human well-being: Synthesis, Island Press, Washington, D.C.

Moore, S.A. 2005, 'Regional delivery of natural resource management in Australia. Is it democratic and does it matter?', in R. Eversole and J. Martin (eds), 2005, Participation and Governance in Regional Development: Global Trends in and Australian Context, Ashgate, Hampshire, England, pp. 121-136.

Moore, S.A. and S.F. Rockloff, 2006, 'Organising regionally for natural resource management in Australia: Reflections on agency and government', Journal of Environmental Policy and Planning, vol. 8(3), pp. 259-277.

Morton, S., G. Bourne, P. Cristofani, P.Cullen, H. Possingham and M. Young, 2002, Sustaining our natural systems and biodiversity: an independent report to the Prime Minister's Science, Engineering and Innovation Council, CSIRO and Environment Australia, Canberra.

Murray, D. 2005, 'A critical analysis of communicative rationality as a theoretical underpinning for collaborative approaches to integrated resource and environmental management', Environments Journal, vol. 33(2), pp. 17-34.

Murray-Darling Basin Ministerial Council (MDBMC) 2001, Integrated catchment management in the Murray-Darling Basin 2001-2010: Delivering a sustainable future, Murray-Darling Basin Commission, Canberra.

National Water Commission (NWC) 2006, Australia's Water Supply Status and seasonal outlook October 2006, Australian Government, National Water Commission, Canberra, viewed 20 January 2007, <http://www.nwc.gov.au/publications/docs/SeasonalOutlook.pdf > 
Rittel, H.W.J. and M.M. Webber, 1973, 'Dilemmas in a general theory of planning', Policy Sciences, vol. 4, pp.155-169.

Saglie, I.L. 2006, 'Fragmented institutions: The problems facing natural resource management', in Y. Rydin and E. Falleth, E (eds), Networks and institutions in natural resource management, Edward Elgar Publishing, Cheltenham, UK, pp. 1-33.

Sabatier , P. A., W. Focht, M. Lubell, Z. Trachtenberg, A. Vedlitz and M. Matlock (eds), 2005, Swimming Upstream: Collaborative Approaches to Watershed Management, MIT Press, Cambridge, MA.

Scholz, J.T. and B. Stiftel (eds), 2005, Adaptive Governance and Water Conflict: New institutions for Collaborative Planning, Resources for the Future, Washington D.C.

Stern, N. 2006, Stern Review on the Economics of Climate Change, viewed 18 November 2006, <http://www.hm-treasury.gov.uk./independent_reviews/stern_review_economics_climate_change/stern_review_report.cfm $>$

Stoker, G. 1998, 'Governance as theory: five propositions', International Social Science Journal, vol. 50(155), pp. 17-28.

Swyngedouw, E. 2005, 'Governance innovation and the citizen: The Janus-face of government-beyond-the-state', Urban Studies, vol. 42 (11), pp.19912006.

The Senate Committee Report 2004, Turning back the tide-the invasive species challenge, The Senate Environment, Communications, Information Technology and the Arts References Committee Inquiry into the regulation, control and management of invasive species and the Environment Protection and Biodiversity Conservation Amendment (Invasive Species) Bill 2002, The Commonwealth of Australia, December 2004.

The Wentworth Group of Concerned Scientists 2003, Blueprint for a National Water Plan, 31 July 2003, WWF, Sydney, viewed 20 November 2006, $<$ http://www.wentworthgroup.org/docs/blueprint_national_water_plan.pdf $>$

\section{6, Australia's Climate is Changing. The State of Australia's Water,} November 2006, viewed 20 November 2006, <http://www.wentworthgroup.org/docs/Australias_Climate_is_Changing_Australial.pdf $>$

WalterTurnbull 2005, Evaluation of current governance arrangements to support regional investment under the NHT and NAP. Final Report, Departments of the Environment and Heritage and Agriculture Fisheries and Forestry, Australian Government, December 2005. <http://www.nrm.gov.au/monitoring/national-evaluations/governance.html $>$ 
Williams, P. 2006, 'The governance of sustainable development in Wales', Local Environment, vol. 11(3), pp.253-267.

\title{
ENDNOTES
}

\begin{abstract}
${ }^{1}$ The term natural resources refers to the soil, water, plants, animals and micro-organisms that maintain our ecosystems (AFFA 1999, p. 1)

${ }^{2}$ In Australia, most legal definitions are based on the definition of ecologically sustainable development (ESD) agreed to by the Australian/Commonwealth, States and local government and embodied in the National Strategy on Ecological Sustainable Development 1992 and the Inter-Governmental Agreement on the Environment 1992; namely 'using, conserving and enhancing the community's resources so that ecological processes, on which life depends, are maintained, and the total quality of life, now and in the future, can be maintained.' (Commonwealth of Australia 1992: p.6).
\end{abstract}

